\title{
PERSONALIZED INFORMATION MANAGEMENT BY ONLINE STORES IN 4C MODEL. CASE STUDY
}

\author{
Anna KUBICKA \\ Warsaw University of Technology, Faculty of Management, Warsaw, Poland \\ e-mail: a.kubicka@wz.pw.edu.pl
}

\begin{abstract}
The increasing complexity of the business environment, growing knowledge requirements, development of information technologies, and competitiveness implies the need of implementation of information management systems. Moreover, welter of information about online customers, their individual behavior, and their expectations force entrepreneurs to manage information in a personalized way. Monitoring Internet users behavior, creating their profiles (based on data about age, sex, lifestyle, interests, family, work, etc.), and controlling current traffic on the Web site give wide range of possibilities in creating a real model of potential customers preference and using it in online communication. This study concentrates on possibilities of using personalized communication in the information management by online stores in $4 \mathrm{C}$ model.
\end{abstract}

Keyword: personalization, information management, e-commerce, 4C model.

\section{Introduction}

Currently, electronic commerce is entering the postPC age, which is characterized by the rapid development of information technologies and innovative electronic communication tools (Dean, Gilliland, 2014). Entrepreneurs, who plan to start online business, must be ready to work in dynamically changing environment, cope with expectations of being flexible and innovative.

Online users expect highly integrated services, combining fast, smooth, and safe transaction process with world-wide availability, at any time of a day, through all types of devices, for example, a smartphone, tablet, laptop, and desktop. Personalized approach to the mass customer seems to be the most important action that ought to be undertaken to manage that expectations (Rubikom Strategy Consultants, 2014).

Nowadays, fast, timely, and decisive response to market changes is one of the main success factors. It can be achieved only by making information and data flow more efficient. Broadly defined information plays supportive role in managing process in XXI century (Malara, Rzęchowski, 2011). Furthermore, it determines company competitiveness and has the same value as capital, material, and human resources (ibidem).
In managing, it is no longer possible to make right and rational decisions without a full, accurate, and timely information. Lack of information is equally undesirable as misleads or accidental decisions caused by, for example, pressures from environment or time. Information shortage implies the need of gathering data, which will give desired profits for entrepreneur. Oleński said that 'information' as an economic resource is potentially useful set of data and metadata, collected and stored in a point in time and place, by using technology and organization, which have to be useful for the end users - economic actors on the market (Oleński, 2001, p.246).

Welter of information and e-customer's individual behavior force entrepreneurs to manage information in a personalized way during interaction with their potential clients (applies to product promotion, product marketing, order fulfillment, and after-sales customer care). Personalized products and services match to customer's needs to help increase the sales' efficiency (Andruszkiewicz, Betcher, 2015, p.91-92).

The article concentrates on possibilities of using the personalized communication in the information management process by online stores in $4 \mathrm{C}$ (customer value, cost, convenience, and communication) model. Theoretical part explains the personalized information phenomenon and its role in information management. Practical part (case study) is based on the knowledge acquired from E-commerce De- 
partment in one of the biggest corporation in Warsaw whose employees take advantage of personalized information in communication with customers in their daily work.

Author conducted research to verify the thesis: "The rapid development of new information technologies allows online stores to collect countless number of information about potential client and offer personalized communication/products, what increase sales effectiveness."

This paper is organized as follows: in the first section, author presents various definitions of "information" and explains the difference between data, information, and knowledge. Second section concentrates on information management. The next part is an overview of personalization research. Author concentrates on personalization determinants and factors; he reviews the personalized information different approaches/strategies, underlines personalization elements which imply the real model of potential customers preferences. The last section discusses the limitations of the work and the practical implications of the research and presents the recommendation for business.

\section{Information}

Information is an essential element of the market environment and companies strategy determinant. Nowakowski and Sobczak defined "information" as "(...) any message, on which the recipient bases his action (...)" (Nowakowski, Sobczak, 1970, p.13). Kisielnicki and Sroka defined "information" as a resource that allows somebody to increase his or her knowledge about himself or herself and the world around him or her (Kisielnicki, Sroka, 2005, p.14). Moreover, they emphasized that collecting and processing information is the way to learning organization (Kisielnicki, Sroka, 2005, p.13-15). Kiełtyka specified that knowledge and information have become important factors of business competitiveness (Kiełtyka, 2011). Similarly, Alvin Toffler (in his wave theory) indicated the new emerging type of economy - an economy founded on knowledge and information (Toffler,1995).

Most of the authors agreed with the statement that information is a set of data (numbers, facts, concepts). Dziuba claimed that the data is unstructured information (Dziuba, 2005). In his theory, data have to be analyzed and selected, because it allows its owner to achieve measurable effects. It finds confirmation in Stoner and Wankel's definition, who say that information is "analyzed or processed data which inform the recipient about the situation" (Malara, Rzęchowski, 2011). A similar definition was presented by Świderska, who refers to an idea that "information is a structured and analyzed message." In her opinion, information is a desirable signal (from sender to recipient) in an appropriate (understandable) form, required to task realization (Świderska, 2003, p.52). Fig. 1 shows the dependencies between data, information, and knowledge.

Turban and Aronson claim that the basic unit of communication process is data stored mostly in various information systems. They lay stress on the fact that even if there is a set of data (still preaggregated), we cannot talk about information yet. Information is created after processing data (Turban, Aronson, 2001, p.349).

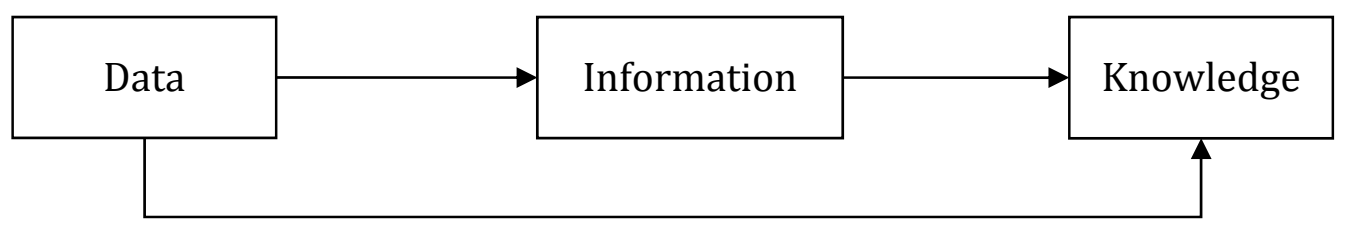

Figure 1. Dependencies between data, information, and knowledge (source: Turban, Aronson, 2001, p.349) 


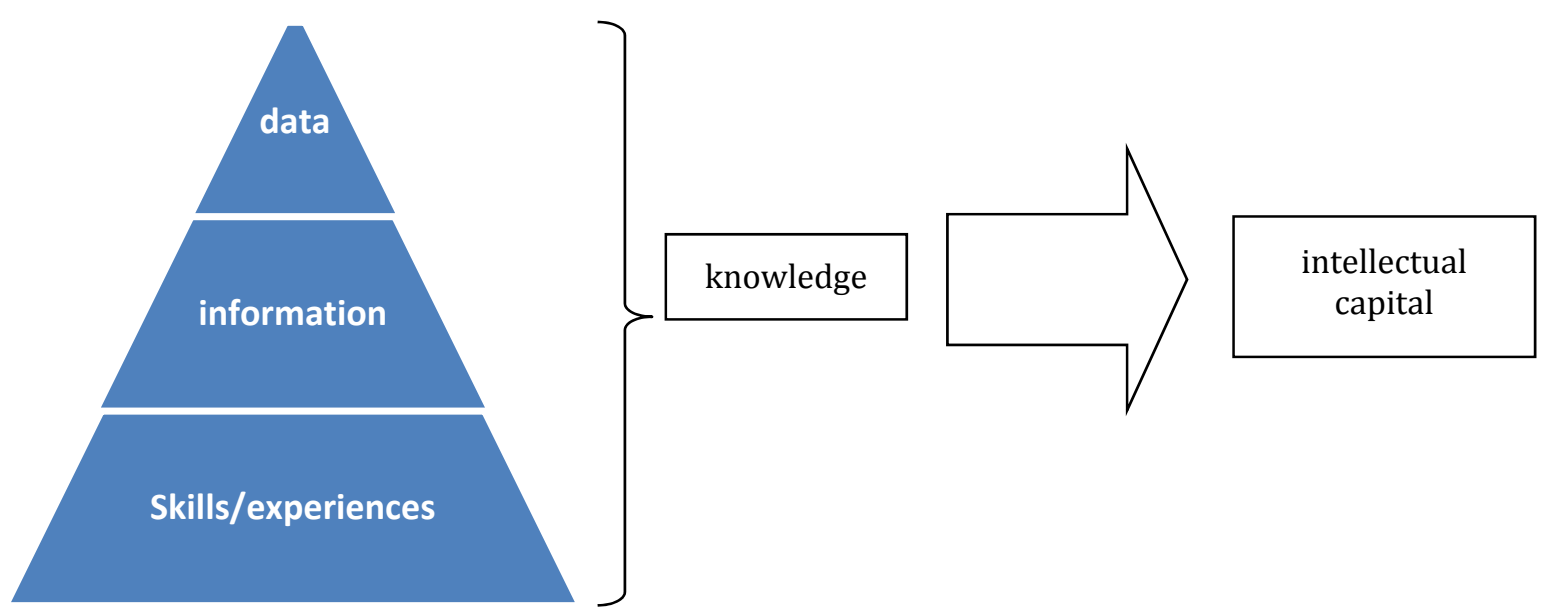

Figure 2. Dependencies between data, information, skills/experiences, and knowledge (source: Malara, 2006, p.128)

Malara added that the information or set of information itself do not generate knowledge. He underlined the importance of skills and experience in processing information. In his opinion, information combined with experience provides knowledge (Malara, 2006) (Fig. 2).

\section{Information management}

Development and technological progress in mass communication (age of smart devices, big data, integrated applications) have a strong impact on the cooperation between the entrepreneur and mass customers. Richard Zagała pointed that the following factors imply the need for information management:

- the increasing complexity of the business environment,

- growing knowledge requirement,

- development of information technology,

- perception of information as a factor of value increase and competitiveness (Zygała, 2007).

Availability of media services and data analysis tools have contributed to the fact that the mass customer making online purchases is handled individually (in his private perception). The result of this fact is that the roles of the sender and the recipient (or intermediary) today belong to both human and the machine (Czekaj, 2000).

Information is a determinant of the new economic order (Drucker, 1994). It can only mean that it should have its reflection in modern management. Gierszewska and Romanowska said that possessing information is needed to identify and carry out tasks that realization is necessary to achieve the organization's goals (Gierszewska, Romanowska, 1997, p.222).

Grudzewski and Hejduk strongly emphasized the role of information in decision-making process: "information can also be considered as data connection (substantive and logical) which enables a feedback" (Grudzewski, Hejduk, 2001).

Created by Davenport, information management process model shows complete information value chain, starting from identifying information needs through organizing, storing, distributing, and using information on the end (Davenport, Prusak, 1997).

Assumption that appears logical is that information has its own market value. George Stigler identified the information as an economic good already in the 1990s (Stigler, 1983). The value of information derived from the data contained in it (Boulding, 1999).

The role of information management is to provide a systematic communication between organization and environment, what in consequence will result with the expected position on the market (Czekaj, 2000). In online stores, information can be used to individualizing messages to mass customers using personalization tools. 


\section{$4 \quad$ Personalized information}

The number of Internet users in Poland has been annually rising. According to the Gemius report (Fig. 3), 70\% of Poles had access to the Internet in 2015 (it is 24,820,000 people). It has incredible growth comparing with data from 2010 (half of polish citizens had access to the Internet in 2010, what gives 18,210,000 people). In 2005, in Poland, only $27 \%$ of citizens were Internet users $(9,550,000)$ (Gemius, 2015).

Fifty-five percent of Poles who have access to the Internet use it for online shopping, what confirms report prepared by Megapanel PBI/Gemius in 2014 (Polskie Badania Internetu Sp. z o.o., 2014) (Fig. 4).

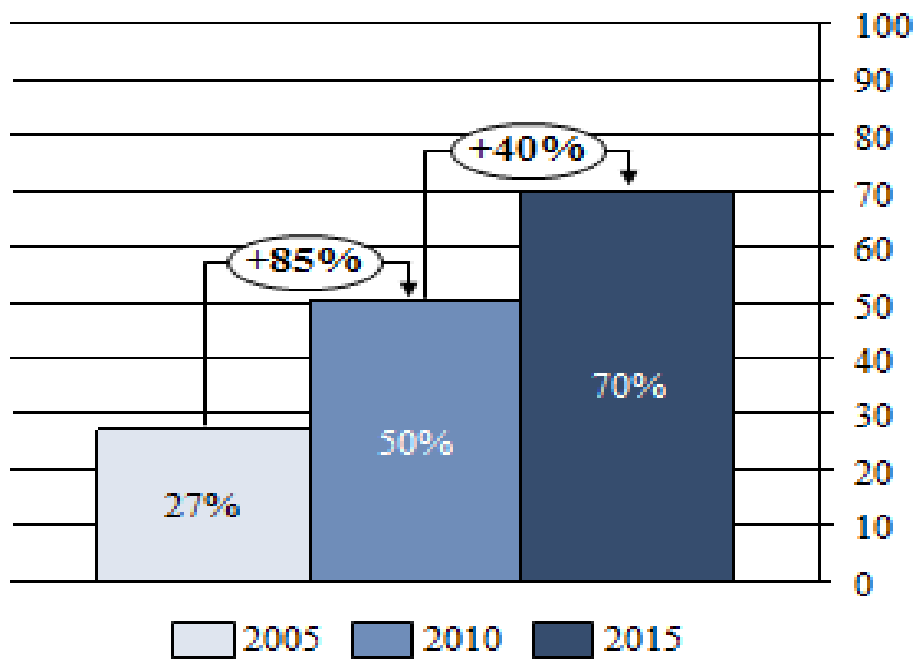

Figure 3. Poles having access to the Internet 2005-2015 (\%) (source: Gemius, 2015)

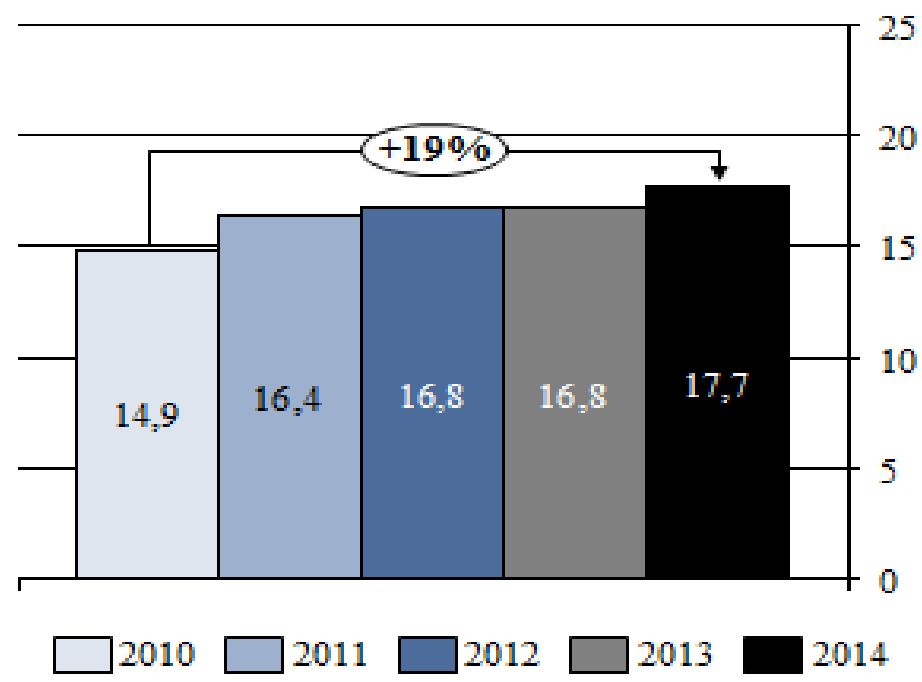

Figure 4. Number of Poles making online purchases (in millions) (source: Polskie Badania Internetu Sp. z o.o./ Gemius, 2014) 


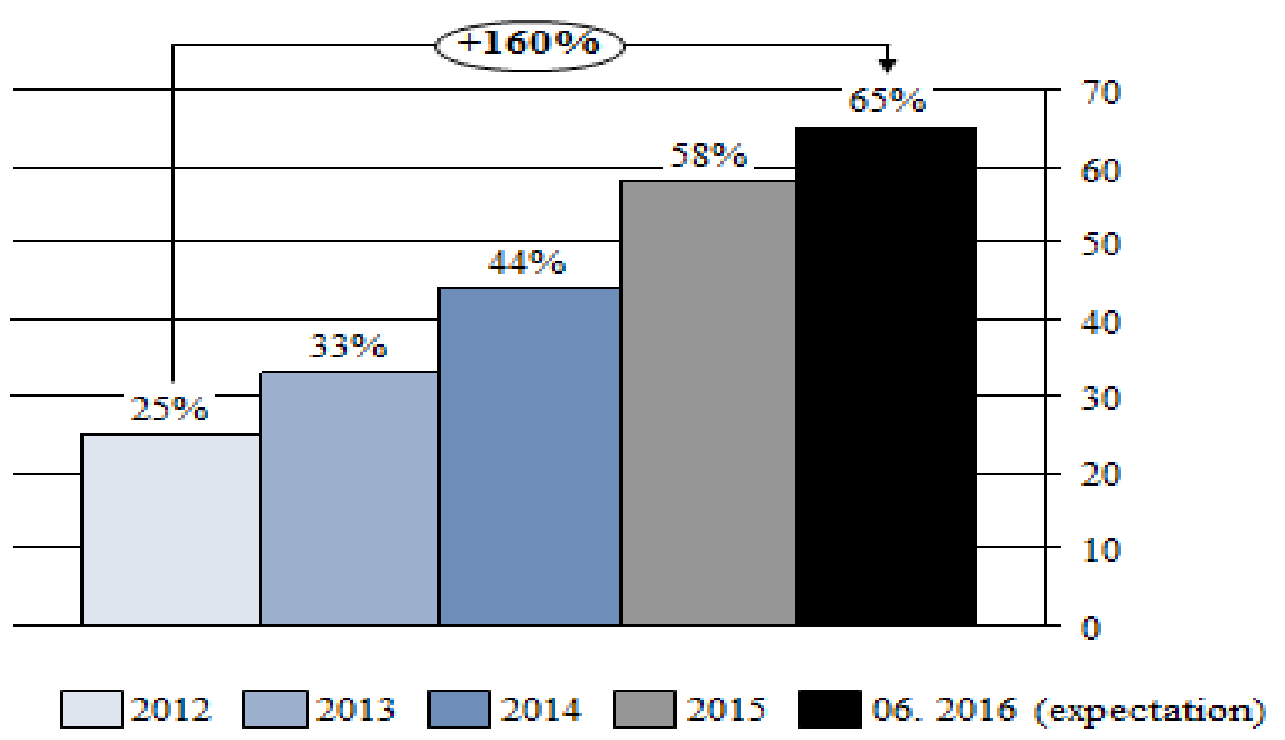

Figure 5. Number of Poles having smartphone (\%) (source: Forbes, 2015)

Latest research indicates that number of online customers in Poland have increased by $20 \%$ in four years.

Figures above presents a state of affairs which is mainly a result of dynamic development of mobile devices market. According to Forbes analysis, year 2015 has ended with level of almost $60 \%$ Poles possessing a mobile phone with access to the Internet (Forbes, 2015) (Fig. 5). Latest prognosis predicts that in half of 2016, almost $70 \%$ of Polish population will be smartphone users (Mikowska, 2015). It will be the main reason of significant increase in the circulation of capital in e-commerce.

Mobile devices revolution, digitization, and development of 4G LTE are the triggers of rapid growth in number of Web pages. The Internet has become more popular medium of information than television because it allows receivers to select information. The thing that is meant by the goal is achieving the highest degree in online users satisfaction with the information which they are recipients. The only way of achieving that is Web pages personalization (Szwarc, 2010).

Personalization uses new information technologies (Yijuan, Nicu, Ross, Qi, 2011) and Internet to individualize mass communication (Kwiseok, Cook- hwan, 2012). Solutions based on personalization help to increase the effectiveness of electronic communication and direct it to specific target groups (customer's segments). Personalized messages stimulate internet users feelings about the content of the offer. Recipient feels unique and distinguished.

The business effect of this proceedings is building long-term relationship with customer (loyalty acquisition).

Why does Business need personalization? Practitioners identify following characteristics of online customers that can be used to satisfy their needs and meet their expectations (Wojciechowski, Zakrzewicz, 2000):

- Internet users read selectively - they do not read all the information contained on the Web page,

- Internet users pay attention to information strongly emphasized, for example, larger font, colors, text in the frames,

- Internet users expect a simplified message that will attract their attention,

- Internet users focus more on graphics than the written words. 
Regarding this, perception and selection of information online customer is limited. This is the reason why online businesses have been forced to create a new model of communication with the potential buyers, which would allow them to increase number of mass customers by drawing clients attention particularly to their offer. The answer to this need is personalization.

It should be noticed that there are three most popular personalization strategies (Reimers, 2000):

\section{1) User-driven personalization}

Online stores that decided to use this type of personalization need to get from the user his or her preferences specification in advance: desired presentation format, layout, interesting for him or her content. Whole process is based on user requirements - he or she has to disposal some professional tools and options to specify his or her needs.

This type of strategy is represented, for example, by travel agencies - customer can view all offers or define his or her journey destination, maximum and minimum price, flights, and hotels. All interesting for him or her information can be displayed on Web site or send via e-mail in preferred format.

\section{2) Transaction-driven personalization}

In this case, personalization is based on user transactions history. There is no need to specified preferences in advance because merchant is analyzing only the history of account, previous transaction, what allows him or her to display similar products or services that could be interesting for specific customer, for example, accessories, maintenance, a new product with similar quality/grade.

\section{3) Context-driven personalization}

This is the most interactive personalization strategy because data interpretation and purchase context recognition take place in a real time. Data analysis continues uninterrupted what allows the mechanism to adapt to the changing context continuously.
Examples of the context-driven personalization are dynamic banners, dynamic offers (when mechanism recognizing up-sell or cross-sell opportunities), dynamic recommendation.

Monitoring Internet users behavior, creating their profiles (based on data about age, sex, lifestyle, interests, family, work, etc.), and controlling current traffic on the Web site give wide range of possibilities in creating a real model of potential customers preference. That knowledge is a good potential to improve the services functionality (adaptation to customer expectations).

The first step in personalizing the online store is users profiling. "User profiling is the process of gathering information specific to each visitor to a Web site either implicitly, using the information hidden in the Web logs or technologies such as cookies, or explicitly, using registration forms, questionnaires, and the like. Such information can be demographic, personal, or even information concerning the user's navigational behavior." (Eirinaki, Vazirgiannis, 2003, p.8).

Companies offering data analysis can provide the following information (Koetsier, 2014):

- who visits a Web site,

- number of page views,

- time spent on subpages,

- words that are typed into a search engine,

- information about any events on www,

- products that potential customer chooses,

- payment methods which customers are interested in,

- traffic path, personal data.

For this purpose, explicit and implicit profiling should be used (literature recommended using both together) (Table 1) (Brusilovski, Kobsa, Nejdl, 2007). 
Table 1. Explicit and implicit profiling comparison

(source: own study based on: Brusilovski, Kobsa., Nejdl (ed.), 2007, p.54-90; Jones, 2015)

\begin{tabular}{|c|c|c|}
\hline & Explicit profile & Implicit profile \\
\hline : & $\begin{array}{l}\text { Information is obtaining directly } \\
\text { from the user - he or she is complet- } \\
\text { ing questionnaire (e.g., during e-mail } \\
\text { account creating, polls, forms, } \\
\text { probes, pop-ups) }\end{array}$ & $\begin{array}{l}\text { Information is based on observing user's behaviors and } \\
\text { reactions. In second step of browsing, schemes } \\
\text { /profiles/segments are made. The data is stored primarily } \\
\text { in logs, cookies, or session tracking modules. }\end{array}$ \\
\hline 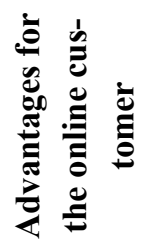 & $\begin{array}{l}\text { User has opportunity to create/dis- } \\
\text { play content preferable for him or } \\
\text { her; he or she does not feel tracked } \\
\text { because his or her preferences are } \\
\text { evident }\end{array}$ & $\begin{array}{l}\text { There is no need to select information because online store } \\
\text { always display information based on data collected about } \\
\text { user preferences. }\end{array}$ \\
\hline 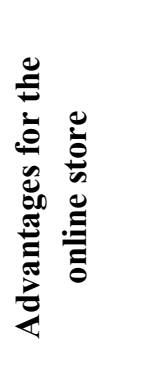 & $\begin{array}{l}\text { Gaining certain information about } \\
\text { user preferences which are con- } \\
\text { firmed/ recommended by user }\end{array}$ & $\begin{array}{l}\text { It gives possibility of following personal/identity-related } \\
\text { data about Internet user: e-mail address, name, location, } \\
\text { demographics, cookies, IP address, social ID, employ- } \\
\text { ment, device ID, social profile, postal address, location- } \\
\text { related data, owned account information, phone number, } \\
\text { lifestyle details, social influence, specific attributes } \\
\text { for your business, family details, psychographics } \\
\text { (Koetsier, 2014). }\end{array}$ \\
\hline 常 & $\begin{array}{l}\text { A high level of subjectivity lack of } \\
\text { interest on user side; incomplete in- } \\
\text { formation }\end{array}$ & $\begin{array}{l}\text { Feeling of insecurity during shopping online; distance } \\
\text { to the tenderer }\end{array}$ \\
\hline
\end{tabular}

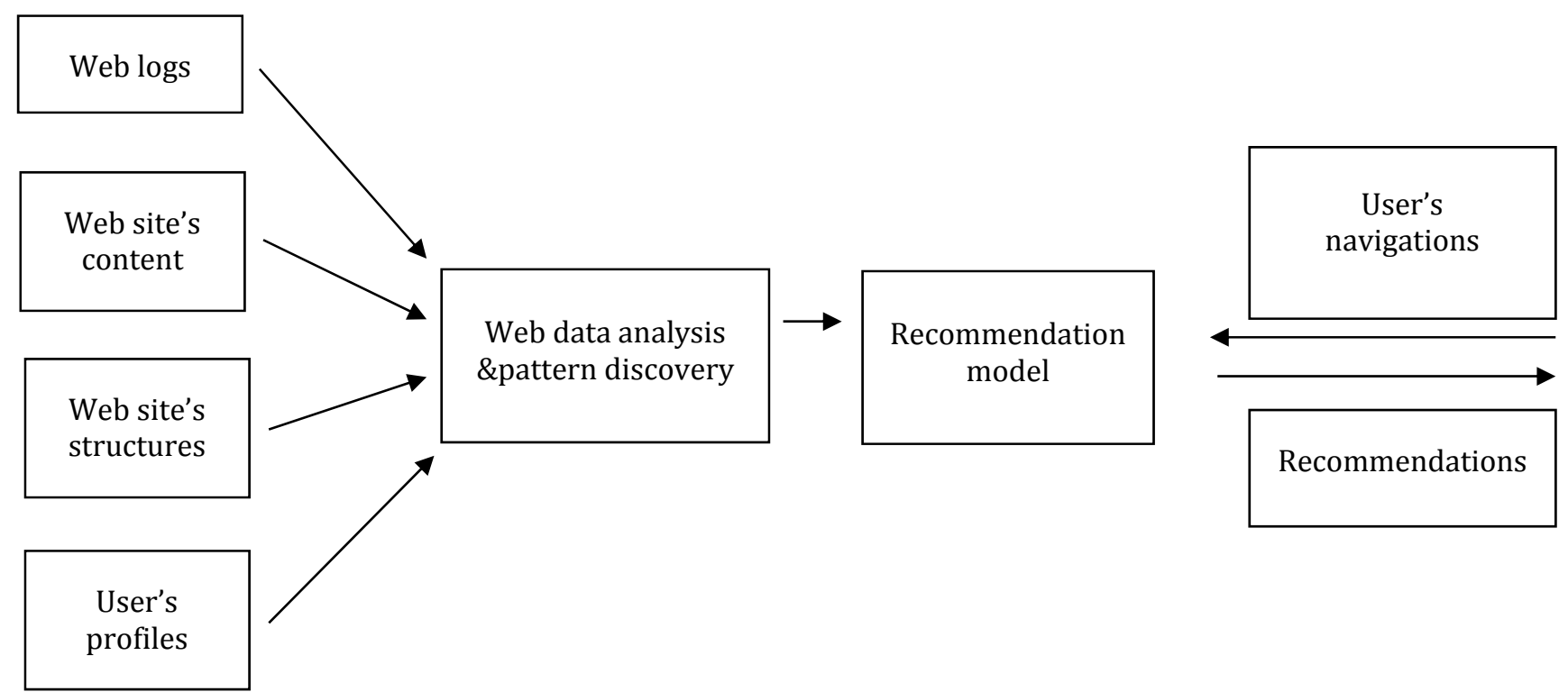

Figure 6 . Web personalization system process (source: Sridevi, Umarani, 2013) 
“Above presented architecture uses Web site's structure, Web logs created by observing the user's navigational behavior and user profiles created according to the user's preferences along with Web site's content, to analyze and extract the information needed for the user to find the pattern expected by the user" (Fig. 6) (Sridevi, Umarani, 2013, p.1533).

Short on time to purchase the product at a local store

Found a product I wanted related to the one I was.

A handful of online stores where I might be able to find. Enough time to complete the transaction on any given day Product availability at my store of choice Sufficient product information (images and copy) Offered an acceptable product at the righr price Found the right product A special offer that includes free shipping A discounted price on the product

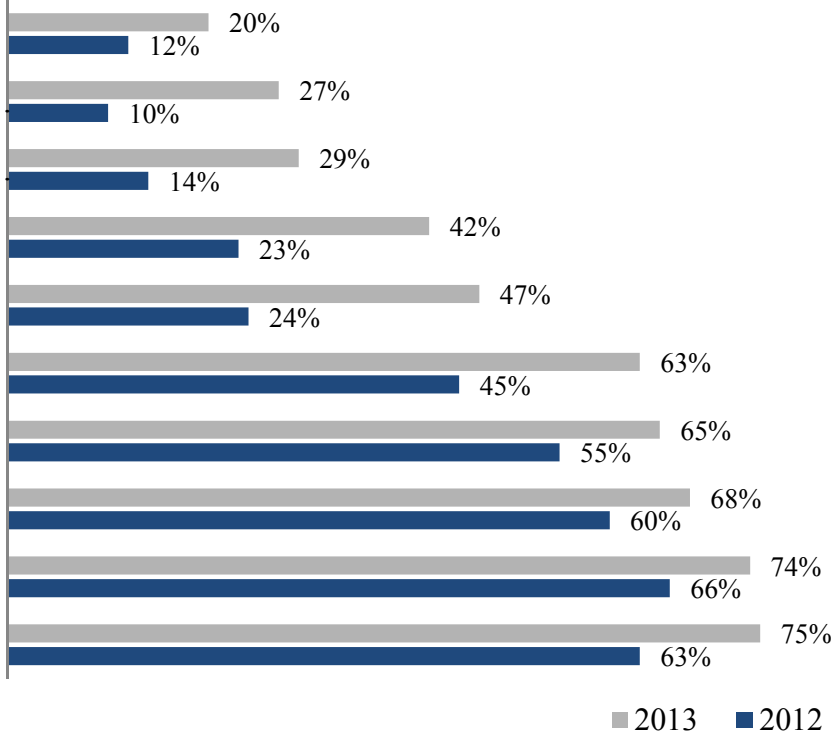

Figure 7. What makes customer "ready to buy?"

(source: MyBuys, 2014. When service fails: Personalization Comes of Age: 2014 Retail and Consumer Insights)
The same research shows that customers expect personalized information everywhere. In Fig. 8, are pre-
MyBuys survey conducted in the United States in 2012-2013 (publication of the results in 2014) shows that the most of Americans buy in online stores. Consumers pointed the following benefits that could induce them to online purchases (Fig. 7) (My Buys, 2014). sented areas identified as preferred for personalized communication.

\section{Social media advertising \\ Mobile advertising \\ Advertising on other websites}

Recommendations via a retailer's email for which you Recomendations on a retailer's website

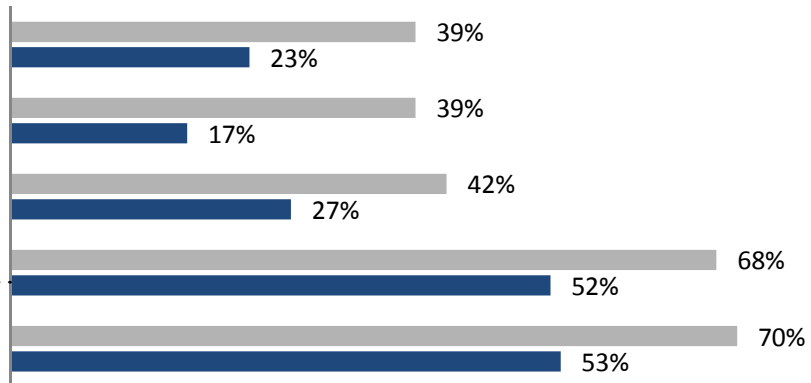

Figure 8. Where you want to receive personalization? (source: MyBuys, 2014. When service fails: Personalization Comes of Age: 2014 Retail and Consumer Insights) 
Elements of personalization received positively by Americans present the Listrak research (2014) cited by eMarketer. Listrak investigated five attitudes toward retailer ads/e-mails by demographic (Senties Technologies, 2015):

- e-mails featuring recommended products based on what buyer previously purchased,

- e-mails featuring recommended products based on what potential client looked at online, but not purchased,

- online ads featuring images of products, previously viewed on a retailer's Web site by receiver,
- e-mails personalization "by using name in the subject line or the body of the email'.

- "Products recommendation on the pages of its Web site" while potential client shopping.

Survey reveals that $80 \%$ of e-mail readers find it useful when e-mails feature recommended products based on past purchases.

Table 2 presents personalization benefits for both sides (online store and online customer).

$\square 1 \backsim 2 \backsim 3 \backsim 4 \square 5$

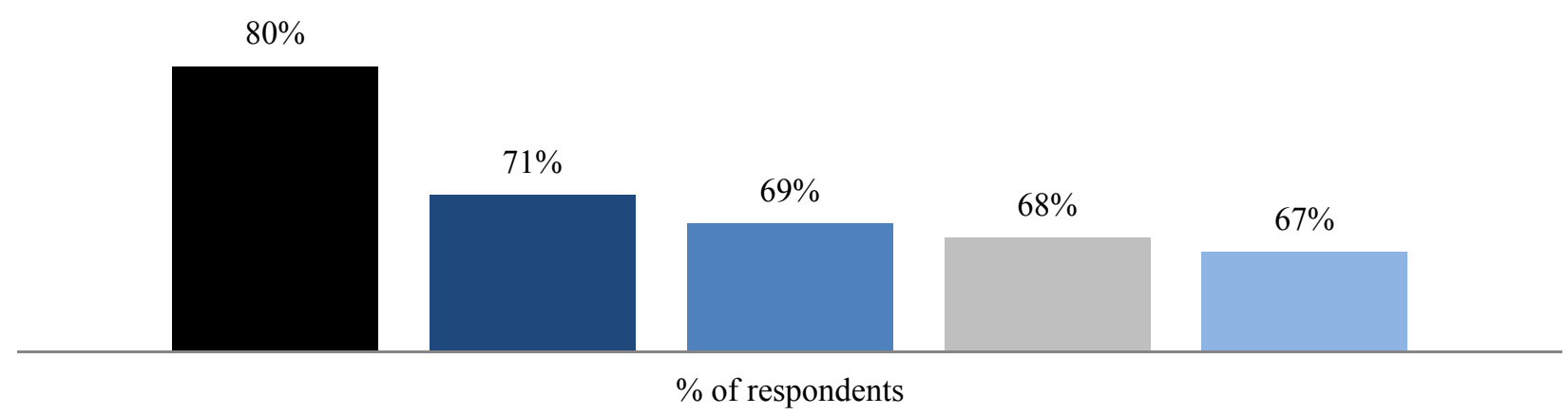

Figure 9. Attitudes toward retailer ads/e-mails among US e-mail users by demographic (source: Senties Technologies, 2015. When service fails: Personalization for retailers roudup)

Table 2. Personalization benefits for online store and online consumer (source: own study based on: Olejniczak, 2004)

\begin{tabular}{|l|l|}
\hline \multicolumn{1}{|c|}{ Benefits for online store } & \multicolumn{1}{c|}{ Benefits for the online customer } \\
\hline- Acquiring loyal users, & - Organizing the web site profile to personal \\
- Possibility of defining the target group, & needs, \\
- Building own address database, & - Concentrating on useful information, \\
- Managing personalized messages to a selected & - Efficient access to interesting offers, \\
& - Individual approach to the client (chat, hotline), \\
- segment of clients, & - The ability of creating customized products \\
- Raising customer satisfaction/recommendations, & (e.g., own composition), \\
- Increasing service attractiveness, & - Possibility of using promotions, discounts, loy- \\
- Increasing competitive advantage, & alty cards, \\
- Acquiring recognition in the internet communi- & - Possibility of getting the most actual infor- \\
ty, & mation (newsletter), \\
- Increasing the number of people staying on Web & - Onsistent visualization on all devic- \\
site. & es(responsible web design). \\
\hline
\end{tabular}


Generally, public opinion is not uniform in personalization case. Some users hold the view that personalization is controversial (especially implicit profile model). They maintain that analyzing traffic on the Web sites using the personal data or verifying indepth the purchases history is a violation on their privacy. They feel spied by unknown tracking systems. The awareness that information about their online activity is collected without their permission make them embarrassed. Research conducted by KPMG and Indiana University in 2014 confirms thesis that part of Americans have a negative stance toward personalization. "For example, 21 percent of shoppers dislike having a handheld scanner tell them which products match their personal profile, 16 percent oppose having a salesperson make recommendations based on their past purchases, and 14 percent object to having shoppers profiles available online. Some shoppers also have reservations about one-click ordering, perhaps due to concerns about the security of their credit-card information" (Kelley, 2015).

\section{Personalized Information Management by online shops in the $4 \mathrm{C}$ model. Case study}

Personalization is already one of the most powerful business trends. According to eMarketer, 49\% marketers in the world plan to increase budgets for per- sonalization. However, most of them create online marketing campaigns on basic information about the user - $57 \%$ use in communication address e-mail, $45 \%$ user name, and $41 \%$ user location (Senties Technologies, 2015).

In this section will be presented practical applications of personalization on e-commerce market adapted to $4 \mathrm{C}$ model.

Model 4C (customer value, cost, convenience, and communication) was proposed by Robert Lauterborn in 1990 as a new formula of Philip Kotler's $4 \mathrm{P}$ theory (product, price, place, promotion). The difference between these two approaches is that Kotler focused on company's point of view, while Lauterborn concentrated on customer's perspective. Both the concepts have the same elements; the new model, however, focuses attention on the recipient of the product and his needs (Lauterborn, 1990).

In the following, 4C concept presented in relation to the online environment. Highlighted set of instruments used to Web sites personalization is the result of observation and tests online stores made by researcher.

\subsection{Customer Value}

1) Presenting only those products and services that relate to the interests of the client (information specified by customer or implicited).

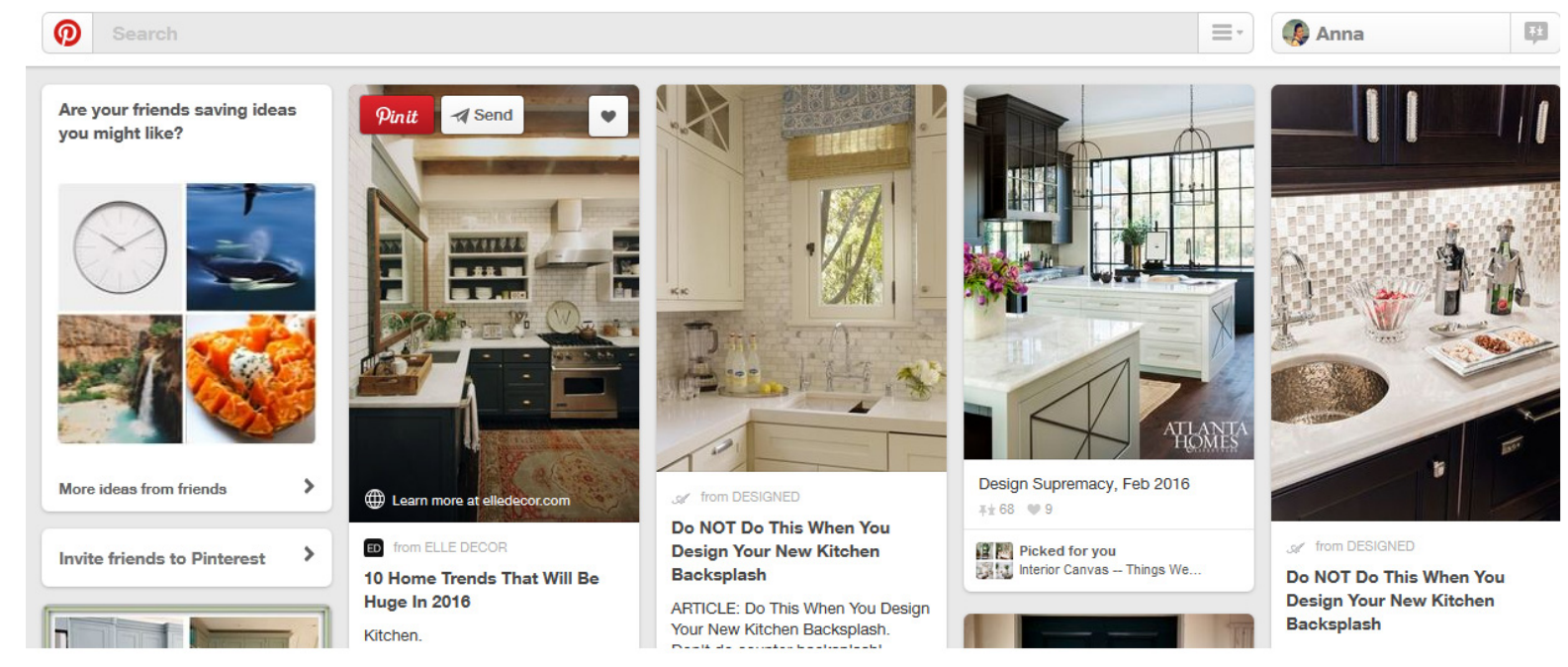

Figure 10. Comment: User was searching information about home equipment After first searching, service displayed another articles in this topic on his board automatically (source: www.pinterest.com) 
2) The ability to configure own product (from offered components) by customer.

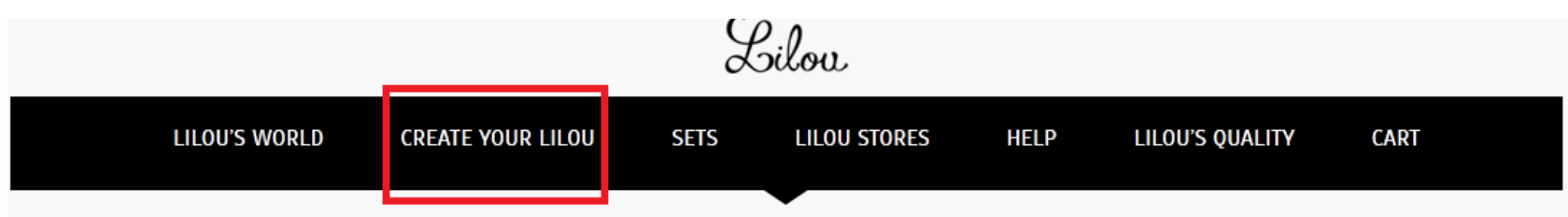

\section{JEWELRY}
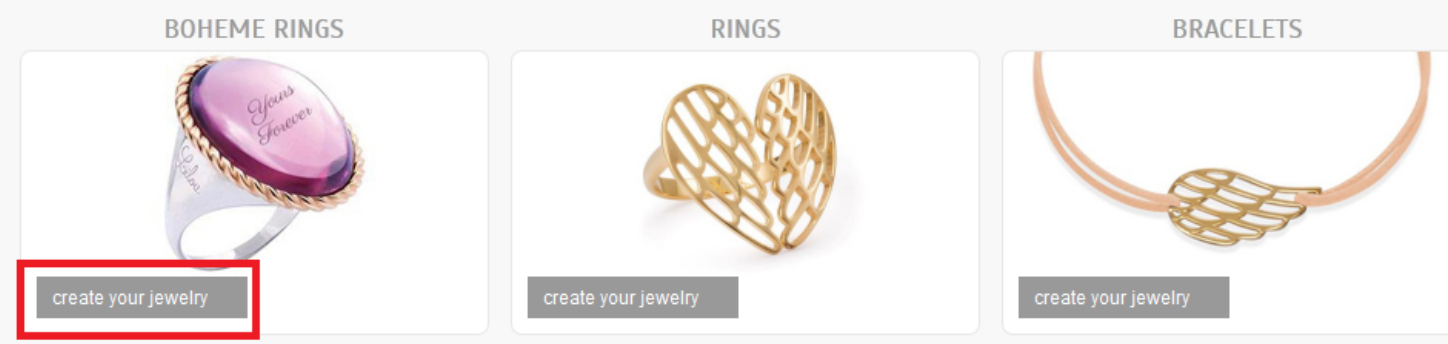

Figure 11. Comment: Lilou gives potential clients possibility to create their own jewelry.

Various elements depend on individual needs, style, taste

(source: www.lilou.pl)

3) Submitting individually composed products or services compatible with customer preferences and lifestyle via e-mail.

\begin{tabular}{l}
\multicolumn{1}{c|}{ UTWÓRZ } \\
Odebrane (22) \\
Oznaczone gwiazdką \\
Ważne \\
Wysłane \\
Wersje robocze (7) \\
Kręgi \\
Personal \\
Travel \\
Więcej - \\
Anna
\end{tabular}

\begin{tabular}{|c|c|c|c|c|}
\hline wakacje & & & & $\begin{array}{r}\text { Codziennie w godzinach 8:00-24:00 } \\
801455401 \\
\text { koszt połączenia } 0,49 \text { zVmin z VAT }\end{array}$ \\
\hline Last Minute & Egzotyka & All Inclusive & Opinie & Forum \\
\hline
\end{tabular}

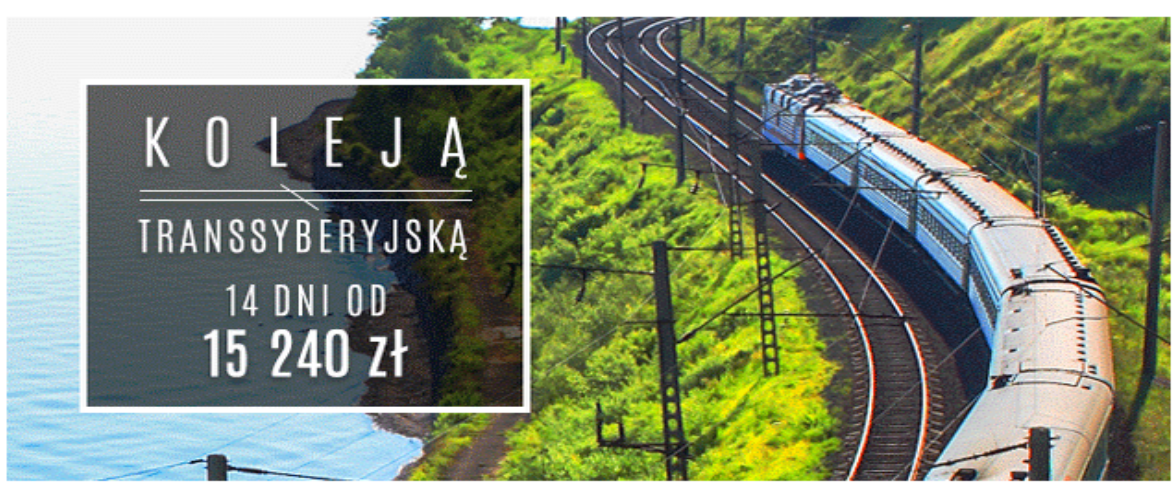

Dalekie podróże czy duża ilość śniegu?

Figure 12. Comment: Service wakacje.pl (holiday) sends regularly to users who put on his or her Web e-mail address the most actual holiday offers

(source: Gmail box) 
4) IP banner with the best deal.

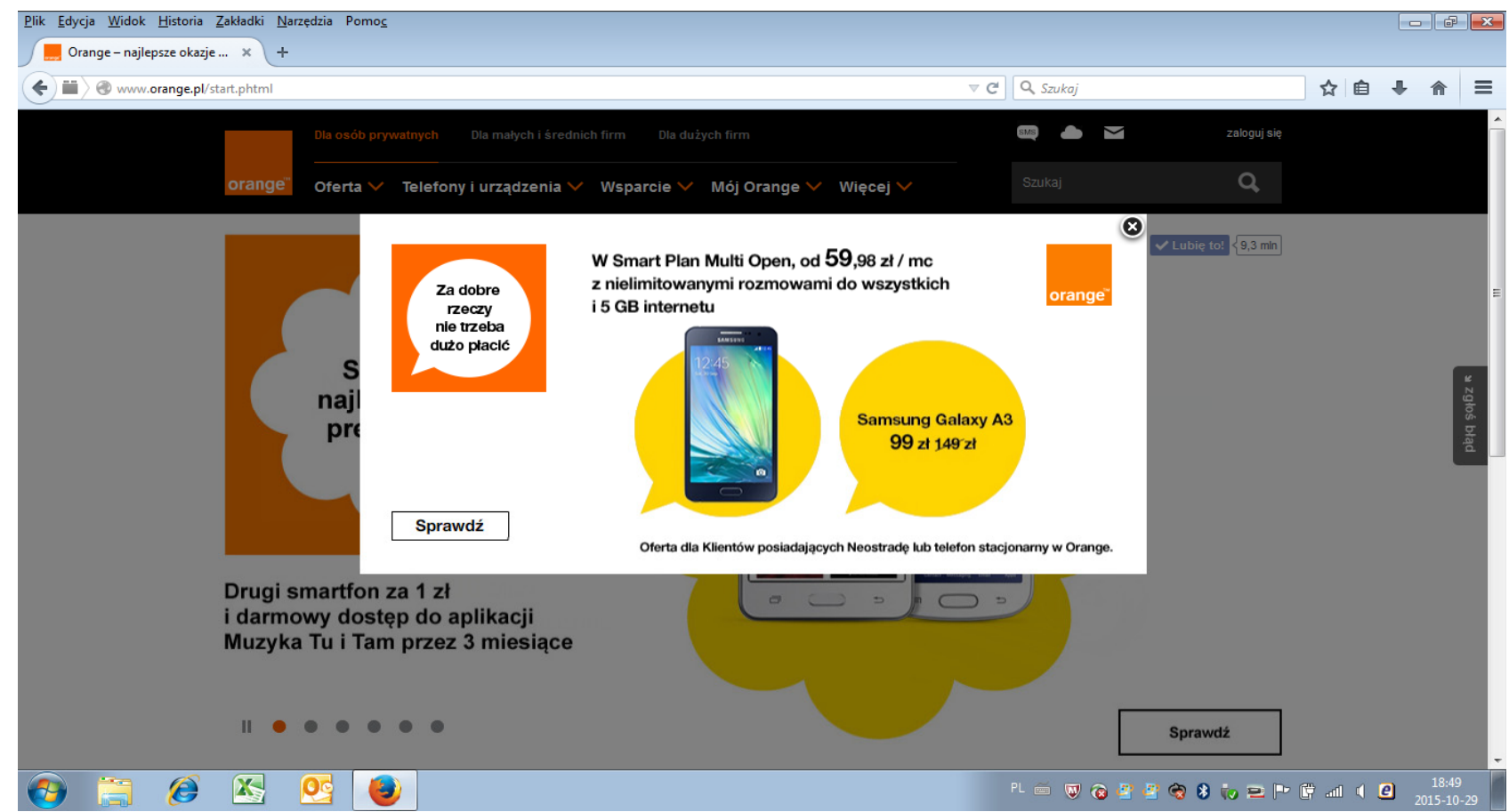

Figure 13. Comment: Orange recognizes the Neostrada's (Orange's service offer access to the internet) IP address and displays mobile phone offer with high discount dedicated to Neostrada's owners (source: www.orange.pl)

5) Presentation of similar products/substitutes in real time.

Product details

- Length: short

- Fit: Waisted

- lining: $100 \%$ polyester

- Bad width: 15.0 " (Size 36)

- Our model's height: Our model is 70.0 " tall and is wearing size 36

- Neokline: Crew neok

- Pattern: Print

- Total length: 36.0 " (Size 36)

- Details: undergarment

- Sleeve length: Extra short

- outer fabric material: $100 \%$ polyester

- Washing instructions: Machine wash at $40^{\circ} \mathrm{C}$, Do not tumble dry, A shrinkage of up

to $5 \%$ may occur

- Article number: NU121C03Y-J11
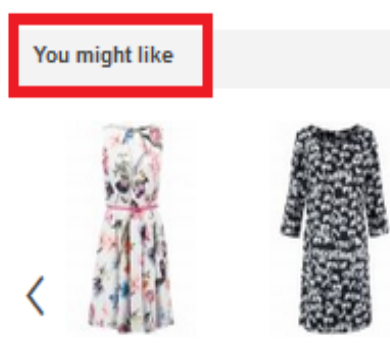

Closet

$£ 60.00$

KIOMI
$£ 45.00$

Wear it with
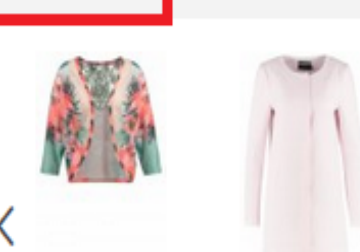

All recommendations $>$

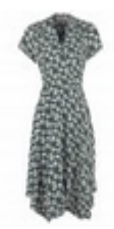

Louche

$£ 39.00$

Louche

$£ 55.00$
All recommendations >

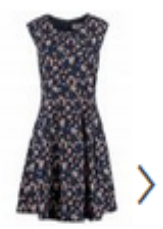

$>$
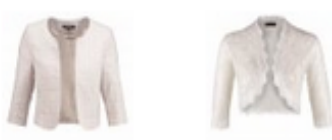

Figure 14. Comment: Zalando.uk analyzes customer's needs and displays similar proposition suitable to viewing product in a real time (source: www.zalando.uk) 
6) Display of products viewed in the previous session on Web page/in Google.

7) Personalized asking about product/shop review.

8) Availability to sign to newsletter.

9) Bestsellers presentation.

10) Availability to order a subscription.

\subsection{Cost}

1) Discounts for the first/current/additional purchases.

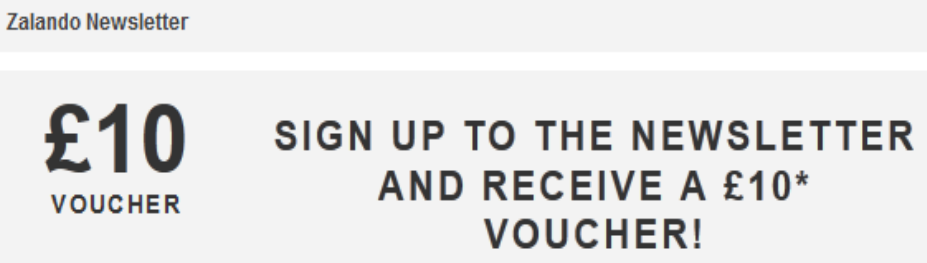

VOUCHER

\section{SIGN UP TO THE NEWSLETTER AND RECEIVE A $£ 10$ * VOUCHER!}

\section{WOMEN} MEN

Figure 15. Comment: Zalando.uk offers discount voucher for purchases with minimal amount (source: www.zalando.uk)

2) Loyalty programs.

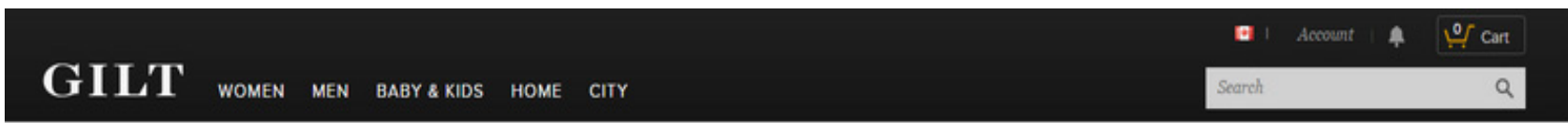

Enjoy US\$9.95 Shipping to Canada!

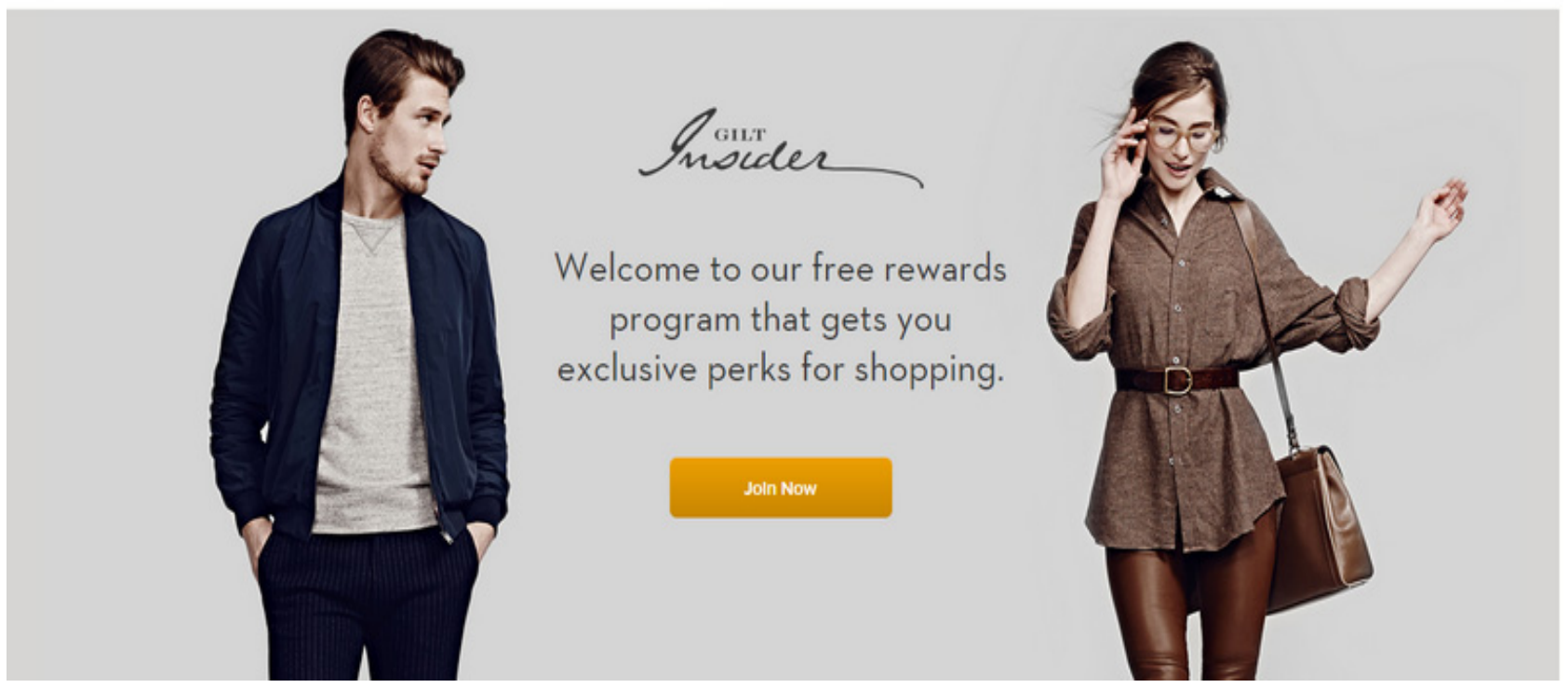

Figure 16. Comment: Gilt builds its addressed base also because of loyalty program which he offered. Potential customer have to give his e-mail address if he want to join to this program

(source: www.gilt.com) 
3) Discounts on purchases if you recommend store your friends.

4) Possibility prices negotiation.

5) Notification about price changes.

6) Contests/games/lottery for customers.

\subsection{Convenience}

- Tools make possible the layout and content on the Web page modifying (the creation of the architecture side, selection of interesting content, selection of graphic design, defining the welcome etc.).

- Search engine on home Web site.

- The ability to use filters, for example, color, size, gender, price, brand, purpose/features.

- Information about historical purchases.

- Various forms of logging, for example, by Google/Facebook.

- Information about product in "bag" (unfinished shopping) during next shopping in the same online store.

- Various forms of payment.

- Notification of the product availability when its failing on stock.

- Various delivery forms.

- Ability to configure preferred delivery hour.

- Information about service security tools.

- Product presentation in Responsible Web Design on mobile device.

- Order statuses.

- In the case of leaving a lead by customer call in a real time.

\subsection{Communication}

- Adverting online users only this information, which match to their interests, sex, age, lifestyle.

- Treating online users personally by directing to them polite phrases - for example, "Welcome to the site John" or "Hello Mrs. John" - is necessary to take into account individual expectations.

- Corresponding with online user in language suitable to their style.
- Displaying ads with products viewed by the user in Google or social media.

- Underlining the strength of the brand (prizes, awards, supporting NGO) on Web site.

- Having funpage in social media.

\section{Summary}

This article analysis confirms adopted thesis. Indeed, advent of the Internet, rapid development of information technology, and innovative electronic communication tools result in a drastic growth of data available in the World Wide Web. It allows online stores to collect countless number of information about potential client.

Furthermore, online customers are bombarded with thousands of information about products and services by marketers, but their perception and selection of information is limited. A wide portfolio of products available on the market offered by online stores implies the need to prepare customers segmentation and users profiles to be more competitive. It is recommended to use solutions based on personalization because it helps to increase the sales effectiveness.

It leads to the conclusion that personalization is the only way to proper information management by e-commerce. These explanations complement each other and help to illuminate the phenomenon of personalization in XXI age.

It is important that any actions based on personalization have to be embedded in the right model, for example, Lauterborn's 4C model, because identification of all the factors affecting the better perception of the online store by customer will lead to business success.

\section{$7 \quad$ References}

[1] Andruszkiewicz, K., Betcher T., 2015. Using big data to customize the offer for customers. International Business and Global Economy, No 34/2015, pp.91-92.

[2] Boulding, K.E., 1999. The Economics of Knowledge and the Knowledge of Economics. American Economic Review, Vol. 56, No. 2, pp.1-13. 
[3] Brusilovski, P., Kobsa, A., Nejdl, W. (ed.), 2007. The Adaptive Web: Methods and Strategies of Web Personalization. Berlin: Springer Science \& Business Media.

[4] Czekaj, J., 2000. Zarządzanie informacją, jako funkcja przedsiębiorstwa. In: T. Borkowski, A. Marcinkowski, A. Oherow-Urbaniec (ed.). $W$ kręgu zarzqdzania. Spojrzenie multidyscyplinarne. Kraków: Księgarnia Akademicka.

[5] Davenport, T., Prusak, L., 1997. Information Ecology. Oxford- New York: Oxford University Press.

[6] Dean, D., Gilliland, G., The Post-PC Era: A Disruptive Dawn. The Boston Consalting Group, [online] Available at:

http://www.bcg.com/expertise_impact/publicatio ns/publicationdetails.aspx?id=tcm:12-

84961\&mid=tcm:12-84951 (Accessed 02.02. 2016).

[7] Drucker, P.F, 1994. The Age of Social Transformation. In: The Atlantic Monthly, No. 11.

[8] Dziuba, D., 2005. Przesłanki rozwoju sieciowych systemów wspomagania decyzji udostępnianych w modelu biznesowym ASP (Evidences of development network systems decision supporting in business model ASP). In: J. Oleński, Z. Olejniczak, J.S. Nowak (ed) Informatyka, strategie I zarzadzanie wiedza. Warszawa: Polskie Towarzystwo Informatyczne.

[9] Eirinaki, M., Vazirgiannis, M., 2003. Web Mining for Web Personalization. In: ACM Transactions on Internet Technology, No 1, pp.1-27.

[10] Forbes, 2015. W 2015 ponad 60 proc. Polaków będzie miało smartfona, [online] Available at: http://www.forbes.pl/w-2015-ponad-60-procpolakow-bedzie-mialo-smartfona,artykuly, 191272,1,1.html\# (Accessed 28.01.2016).

[11] Gemius, 2015. E-commerce w Polsce 2015. Gemius dla e-Commerce Polska,[online] Available at:https://www.gemius.pl/files/reports/Ecommerce-w-Polsce-2015.pdf (Accessed 04.02. 2016).

[12] Gierszewska, G., Romanowska, M., 1997. Analiza strategiczna przedsiębiorstwa. Warszawa: PWE.

[13] Grudzewski, M., Hejduk, I.K., 2001. Globalizacja a kierunki rozwoju zarządzania. Ekonomika i Organizacja Przedsiębiorstw, No 1/2001.
[14] Jones, A., 2015. Identity and Marketing: Capturing, Unifying and Using Customer Data to Drive Revenue Growth, [online] Available at: http://insight.venturebeat.com/report/customeridentity-marketing-capturing-storing-andenriching-right-data (Accessed 05.02.2016).

[15] Kelley (2015). What Consumer want in the physical and virtual store. Creating the ideal shopping experience, [online] Available at: http://kelley.iu.edu/CERR/files/iukpmg00b.pdf (Accessed 05.02.2016).

[16] Kisielnicki, J., Sroka, H., 2005. Systemy informacyjne biznesu. Informatyka dla zarzqdzania. Warszawa: Placet.

[17] Kiełtyka, L. (ed.), 2011. IT Tools in Management and Education. Selected Problems. Częstochowa: The Publishing Office of Czestochowa University of Technology.

[18] Koetsier, J., 2014. Top 10 Marketing Automation companies: The VB Index report 2014. [online] Available at:

http://venturebeat.com/2014/02/26/top-10marketing-automation-companies-the-vb-indexreport/ (Accessed 15.01.2016). [please compare offer portfolio following companies: Hubspot, Salesforce, Marketo, SAS, Eloqua, IBM, ActOn, InfusionSoft, LoopFuse, Silverpop].

[19] Kwiseok, K.,Cookhwan, K., 2012. How to design personalization in a context of customer retention: Who personalizes what and to what extent? Electronic Commerce Research and Applications, Vol. 11, pp.101-116.

[20] Lauterborn, B., 1990. New Marketing Litany: Four P's Passe: C-Words Take Over. Advertising Age, No.61(41).

[21] Malara, Z., 2006. Przedsiębiorstwo w globalnej gospodarce: wyzwania wspótczesności (The company in the global economy: the challenges of modernity). Warszawa: PWN.

[22] Malara, Z., Rzęchowski, J., 2011. Zarządzanie informacja na rynku globalnym. Teoria i praktyka. Warszawa: C.H. Beck.

[23] Mikowska, M., 2015. Marketing mobilny w Polsce 2015 (Mobile Marketing in Poland 2015), [online] Available at:

http:/www.tnsglobal.pl/coslychac/files/2015/05/ POLSKA_JEST_MOBI_2015.pdf (Accessed 29.01.2016). 
[24] MyBuys, 2014. Personalization Comes of Age: 2014 Retail and Consumer Insights, [online] Available at: http://www.mybuys.com/wpcontent/uploads/MyBuys-eTailing-ConsumerSurvey-eBook-May-2014.pdf

(Accessed 03.02. 2016).

[25] Nowakowski, J., Sobczak, W., 1970. Teoria informacji. Warszawa: WNT.

[26] Oleński, J., 2001. Ekonomika informacji. Warszawa: PWE.

[27] Olejniczak, T., 2004. Personalizacja w kształtowaniu lojalności klientów w internecie. Acta Universitatis Lodziensis, No 179.

[28] Polskie Badania Internetu Sp. z o.o./ Gemius, 2014. Wyniki badania Megapanel PBI/Gemius za grudzień 2014. [online] Available at: https://www.gemius.pl/wszystkie-artykulyaktualnosci/wyniki-badania-megapanelpbigemius-za-grudzien-2014.html (Accessed 28.01.2016).

[29] Reimers, B.D., 2000. Getting Personal. InformationWeek, No 767, pp.51-54.

[30] Rubikom Strategy Consultants, 2014. Konsument Digitalny a wirtualna rzeczywistość. Przewodnik po raportach o digitalizacji rynku (Digital Consumer and virtual reality. Guide on reports about digital market), [online] Available at: http://www.shoppingshow.pl/raporty/ShoppingS how_2014_RAPORT_konsument_digitalny_a wirtualna_rzeczywistosc.pdf (Accessed 02.02. 2016).

[31] Senties Technologies, 2015. Personalization for retailers roudup, [online] Available at: https://www.emarketer.com/public_media/docs/eM
arketer_Personalization_Retailers_Roundup.pdf (Accessed 06.2.2016).

[32] Sridevi, K., Umarani, R., 2013. Web personalization approaches: a survey. International Journal of Advanced Research in Computer and Communication Engineering, Vol. 2, Issue 3.

[33] Stigler, G. (ed.), 1983. The Economics of Information. In: Stigler G., The Organization of Industry. Chicago: University of Chicago Press.

[34] Szwarc, N., 2010. Od masowej komunikacji marketingowej po personalizację $\mathrm{w}$ emarketingu. E-mentor, No 3 (35), [online] Available at:

www.e-mentor.edu.pl/artykul/index/numer /35/id/762 (Accessed 10.01.2016).

[35] Świderska, G.K., 2003. Informacja zarzadcza $w$ procesie formulowania $i$ realizacji strategii firmy. Warszawa: Difin.

[36] Toffler, A., 1995. Third wave. Warszawa: PIW.

[37] Turban, E., Aronson, J., 2001. DSS and Intelligent Systems. New Jersey: Prentice Hall.

[38] Wojciechowski, M., Zakrzewicz, M., 2000. Automatyczna personalizacja serwerów $W W W$ $z$ wykorzystaniem metod eksploracji danych, [online] Available at: www.cs.put.poznan.pl (Accessed 25.01.2016).

[39] Yijuan, L., Nicu, S., Ross, H., Qi, T., 2011. Personalization in multimedia retrieval: A survey. Multimedia Tools and Applications, Vol. 51, pp.247-277.

[40] Zygała, R., 2007. Podstawy zarzadzania informacja $w$ przedsiębiorstwie. Wrocław: Wydawnictwo Akademii Ekonomicznej. 